\title{
Analisis Kelayakan Rekondisi Pembangkit Listrik Tenaga Surya Kodingareng 400 kW
}

\author{
Shemina ${ }^{1}$, Suryanto ${ }^{2}$, Musrady Mulyadi $^{3}$ \\ 1,2,3 Jurusan Teknik Mesin, Politeknik Negeri Ujung Pandang. Makassar 90245, Indonesia \\ suryanto@poliupg.ac.id
}

\begin{abstract}
Abstrak- Kondisi geografis Indonesia yang terdiri dari ribuan pulau menyebabkan masih banyaknya daerah terpencil yang belum terjangkau listrik PLN. Masih banyak daerah-daerah terpencil yang belum terjangkau oleh jaringan listrik.Salah satu pulau yang memanfaatkan potensi energi surya adalah Pulau Kodingareng yang memiliki PLTS dengan kapasitas $400 \mathrm{~kW}$, namun sekarang ini PLTS tersebut mengalami kerusakan pada komponen baterai dan inverter. Sehingga studi ini akan menganalisis kelayakan rekondisi PLTS Kodingareng dengan menggunakan dua skema. Rekondisi skema 1 mengganti komponen yang mengalami kerusakan sesuai dengan spesifikasi yang ada pada saat ini, sedangkan rekondisi skema 2 mengganti komponen yang mengalami kerusakan berdasarkan perhitungan ulang dari kebutuhan pembangkit yang tersedia.Berdasarkan dari hasil perhitungan yang menggunakan metode Net Present Value (NPV) dan metode Internal Rate of Return (IRR). Kita dapat menyimpulkan dari hasil analisis rekondisi skema 1 diperoleh hasil yang tidak layak pada kedua metode dengan nilai dari NPV yaitu

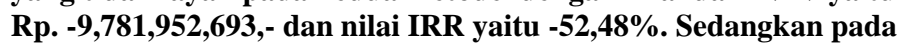
analisis rekondisi skema 2 diperoleh hasil layak pada kedua metode yang digunakan, dengan nilai dari NPV yaitu Rp. 1,112.194.399,-dan nilai IRR yaitu $24,24 \%$.
\end{abstract}

Kata kunci: Net Present Value (NPV), Internal Rate of Return (IRR), PLTS.

\section{Pendahuluan}

Kondisi geografis Indonesia yang terdiri dari ribuan pulau menyebabkan masih banyaknya daerah terpencil yang belum terjangkau listrik PLN. Selain dari pada itu Indonesia sebagai negara tropis mempunyai potensi energi surya yang tinggi dengan radiasi harian rata-rata (insolasi) sebesar 4,5 $\mathrm{kWh} / \mathrm{m}^{2} /$ hari [1]. Potensi ini dapat dimanfaatkan sebagai sumber energi alternative yang murah dan tersedia sepanjang tahun.Oleh karena itu penerapan teknologi Pembangkit Listrik Tenaga Surya (PLTS) untuk memanfaatkan potensi energi surya pada pulau-pulau terpencil tersebut merupakan solusi yang tepat.

Selain itu sumber energi matahari merupakan sumber energi alternatif yang ramah dengan lingkungan, tidak menghasilkan polusi yang dapat merusak ekosistem sekitar.

Salah satu pulau yang memanfaatkan potensi energi surya adalah Pulau Kodingareng. Suplai listrik masyarakat Kodingareng sendiri berasal dari PLTD dan PLTS milik dari PT. PLN (Persero) Rayon Mattoanging. Kapasitas PLTS $400 \mathrm{KWp}$, namun PLTS yang ada di Pulau Kodingareng sejak November 2017 mengalami kerusakan komponen Baterai dan Inverter.

Studi ini memilki tujuan membahas kelayakan finansial jika dilakukan rekondisi pada PLTS Kodingareng yaitu penggantian atau perbaikan pada komponen yang mengalami kerusakan dengan menggunakan dua skema rekondisi.

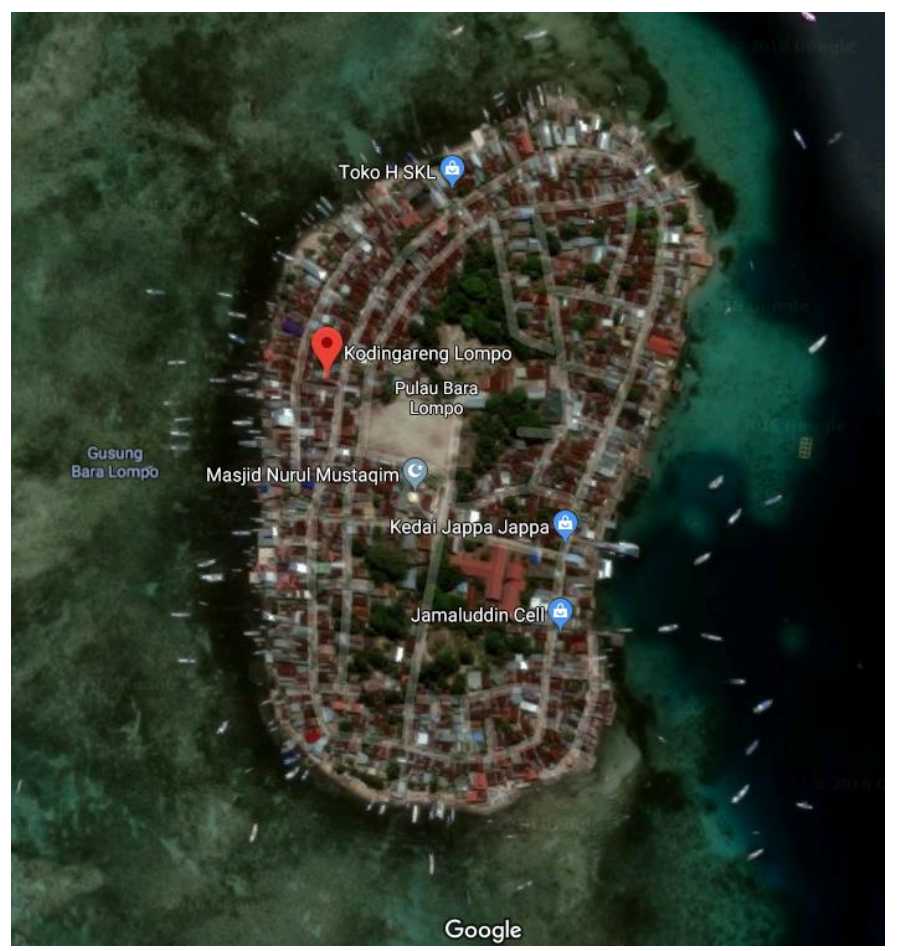

Gambar 1. Kondisi geografis Pulau Kodingareng

\section{LANDASAN TEORITIS}

\section{A. Rekondisi Pembangkit}

Rekondisi pembangkit yaitu mengembalikan kondisi pembangkit dalam kondisi yang normal. Dilakukan rekondisi dikarenakan terjadi kerusakan komponen sehingga pembangkit tidak dapat bekerja dengan baik. Rekondisi ini dilakukan dengan cara melakukan perbaikan di bagian yang mengalami kerusakan dan mengganti komponen jika sudah tidak dapat diperbaiki lagi. Dengan proses perbaikan dan penggantian komponen diharapkan pembangkit dapat beroperasi kembali dengan baik dan normal.

Pada studi ini rekondisi yang dibagi menjadi dua skema rekondisi yaitu : Rekondisi skema 1 diasumsikan perbaikan ataupun penggantian komponen yang mengalami kerusakan tanpa merubah jumlah dan spesifikasi dari komponen yang rusak tersebut. Sedangkan Rekondisi skema 2 diasumsikan redesain 
PLTS dengan merencanakan terlebih dahulu kebutuhan dan bagian pembangkit yang masih dalam keadaan baik.

\section{B. Perencanaan Kapasitas Baterai PLTS}

Pada rekondisi skema 2 penulis akan menghitung kapasitas baterai untuk PLTS Kodingareng sesuai dengan jumlah panel surya atau modul Photo Voltaic(PV) yaitu 2106 modul dan kapasitas pembangkit terpasang yaitu $200 \mathrm{~kW}$ dengan menggunakan beberapa langkah perencanaan sebagai berikut [2]:

1) Menentukan arus beban total dalam Ampere-Jam (Amperehours atau $A h)$.

Arus beban total dapat ditentukan dengan membagi rating Watt maksimum pembangkit dengan tegangan operasi sistem Tegangan Puncak (Peak Voltage/PV) nominal.

2) Rugi-rugi dan Faktor Keamanan (Safety Factor atau SF) Sistem.

Untuk sistem PLTS faktor $20 \%$ harus ditambahkan ke pembebanan sebagai pengganti rugi-rugi sistem dan untuk faktor keamanan. Oleh karena itu Ampere-Jam beban yang ditentuka pada langkah (1) dikalikan dengan 1,2 sehingga:

$$
\mathrm{I}_{\text {aktual }}=\mathrm{I}_{\text {tot_beban }} \times 1,2
$$

3) Menentukan Kapasitas Baterai untuk Waktu Cadangan yang dianjurkan.

Umumnya sistem pembangkit listrik tenaga surya dilengkapi dengan baterai penyimpanan (aki) untuk menyediakan energi pada beban ketika beroperasi pada malam hari atau pada waktu cahaya matahari kurang.Kapasitas waktu cadangan yang disarankan bervariasi berdasarkan garis lintang daerah tempat pemasangan panel surya yang diperlihatkan pada Tabel 1 [1].

TABEL 1.

TABEL TREC YANG DISARANKAN BERDASARKAN GARIS LINTANG

\begin{tabular}{|c|c|}
\hline Garis lintang lokasi pemasangan & Waktu Cadangan (trec) \\
\hline $0^{0}-30^{0}$ (Utara atau Selatan) & $5-6$ hari \\
\hline $30^{0}-50^{\circ}$ (Utara atau Selatan $)$ & $10-12$ hari \\
\hline $50^{0}-60^{0}$ (Utara atau Selatan $)$ & 15 hari \\
\hline
\end{tabular}

Berdasarkan peta insolasi dunia [1], letak wilayah Indonesia terletak pada $10^{\circ} \mathrm{LS}-10^{\circ} \mathrm{LU}$.Ini berarti bahwa waktu cadangan untuk seluruh wilayah Indonesia adalah 5-6 hari. Kapasitas Ampere-Jam (Ah) minimum dari baterai dihitung dengan persamaan:

$$
\text { Baterai }_{\text {cap }}=\mathrm{I}_{\text {aktual }} \times \mathrm{t}_{\text {rec }}
$$

Di mana :

$\begin{array}{ll}\text { Baterai }_{\text {cap }} & =\text { kapasitas baterai }(\mathrm{Ah}) \\ \mathrm{t}_{\text {rec }} & =\text { waktu cadangan }\end{array}$

4) Menentukan Kebutuhan Arus Total Panel Surya

Arus total panel surya yang dibutuhkan dengan cara membagi Total beban + Rugi-rugi dan Safety Factor dengan ESH atau:

$$
I_{\text {tot_panel }}=\frac{I_{\text {tot_beban }} \times 1,2}{E S H}
$$

Di mana berdasarkan peta insolasi matahari dunia diperoleh Equivalent Sun Hours (ESH) untuk Wilayah Sulawesi adalah $4,5[3]$.

5) Menentukan Susunan Modul Optimal untuk Panel Surya

Penyusunan optimal adalah suatu cara yang dilakukan untuk menentukan kebutuhan arus total panel dengan jumlah modul seminimal mungkin. Penentuan konfigurasi modul minimal dengan menghitung jumlah minimal modul yang menyediakan nilai arus panel yang dibutuhkan dan ditentukan pada:

- Jumlah modul paralel

$\sum$ Modul pararel $=\frac{\mathrm{I}_{\text {tot_panel }}}{\mathrm{I}_{\text {op_modul }}}$

Di mana :

$\mathrm{I}_{\text {tot_panel }}=$ arus total panel

$\mathrm{I}_{\mathrm{op} \_ \text {modul }}=$ arus operasi modul

- Jumlah modul seri

$\sum$ Modul seri $=\frac{\mathrm{v}_{\text {system }}}{\mathrm{v}_{\text {op_modul }}}$

Di mana :

$\mathrm{V}_{\text {system }}=$ tegangan nominal system

$\mathrm{V}_{\text {op_modul }}=$ tegangan operasi modul

- Total modul yang diperlukan

$$
\sum \text { Total modul }=\frac{\mathrm{I}_{\text {tot_panel }}}{\mathrm{I}_{\text {op_modul }}} \times \frac{\mathrm{V}_{\text {system }}}{\mathrm{V}_{\text {op_modul }}}
$$

\section{Studi Kelayakan}

Studi kelayakan proyek merupakan suatu studi untuk menilai proyek yang akan dikerjakan di masa mendatang [4].Sementara menurut [5] yang dimaksud dengan studi kelayakan proyek adalah "penelitian tentang dapat tidaknya suatu proyek (biasanya merupakan proyek investasi) dilaksanakan dengan berhasil".

Salah satu kriteria dalam analisis kelayakan adalah net present value (NPV).NPV suatu proyek adalah selisih antara nilai sekarang manfaat dengan arus biaya.Dalam menghitung NPV perlu ditentukan tingkat suku bunga yang relevan. Kriteria investasi berdasarkan NPV yaitu [6]:

1). $\mathrm{NPV}=0$, artinya proyek tersebut mampu mengembalikan persis sebesar modal sosial Opportunity Cost faktor produksi normal atau dengan kata lain, proyek tersebut tidak untung dan tidak rugi.

2). NPV $>0$, artinya suatu proyek sudah dinyatakan menguntungkan dan dapat dilaksanakan.

3). NPV $<0$, artinya proyek tersebut tidak menghasilkan nilai biaya yang digunakan atau dengan kata lain, proyek tersebut merugikan dan sebaiknya tidak dilaksanakan.

Suatu proyek menghadapi ketidakpastian karena dipengaruhi perubahan-perubahan baik dari sisi penerimaan atau pengeluaran yang akhirnya akan mempengaruhi tingkat kelayakan proyek. Analisis sensitivitas bertujuan untuk melihat apa yang akan terjadi dengan hasil analisa proyek jika ada suatu kesalahan atau perubahan-perubahan dalam dasar-dasar 
perhitungan biaya dan manfaat. Pada umumnya proyek-proyek yang dilaksanakan sensitif berubah-ubah akibat empat masalah yaitu harga, kenaikan biaya, keterlambatan pelaksanaan, dan hasil [7].

\section{Biaya Energi Listrik}

Menganalisis suatu proyek akan dijumpai dengan berbagai macam variabel biaya-biaya. Menurut [6] biaya-biaya tersebut dikelompokkan menjadi dua, yaitu :

\section{- Biaya Modal (Capital Cost)}

Definisi dari biaya modal adalah jumlah semua pengeluaran yang dibutuhkan mulai dari pra studi sampai dengan proyek selesai dibangun. Semua pengeluaran yang termasuk biaya modal ini dibagi menjadi dua yaitu [8]: Biaya Langsung (Direct Cost) dan Biaya Tak Langsung (Indirect Cost).

- Biaya Tahunan (Annual Cost)

Biaya tahunan adalah biaya yang yang harus dikeluarkan oleh pemilik/investor setelah proyek selesai dibangun dan mulai dimanfaatkan. Biaya tahunan ini dikeluarkan selama umur rencana proyek yang sesuai dengan rekayasa teknik yangtelah dibuat pada waktu detail desain. Biaya tahunan ini terdiri dari tiga komponen, yaitu [8]: Bunga, Depresiasi atau Atmortisasi dan Biaya Operasi Pemeliharaan.

Pada penelitian ini penulis akan fokus menghitung jumlah biaya yang disisihkan per periode untuk akumulasi dari investasi yang dapat terdepresiasi pada waktu tertentu dengan menggunakan Metode sinking fund dengan asumsi bunga tetap. Dalam hal ini terdapat suatu angsuran tetap tiap tahunnya ditambah dengan bunga terhadap modal investasi.Namun dalam menghitung angsuran ini digunakan metode bunga majemuk yang mulai diterapkan pada tahun pertama. Perhitungan dapat menggunakan persamaan sebagai berikut [9]:

$$
A=\left[\frac{(P-S) r}{(1+r)^{n+1}-(1+r)}\right]
$$

Jadi biaya total depresiasi yang harus disisihkan setiap tahunnya adalah :

Di mana :

$$
q=A+\operatorname{Pr}
$$

$\mathrm{A}=$ jumlah yang disihkan per periode untuk akumulasi dari invetasi yang dapat terdpresiasi pada waktu ke-n

$\mathrm{n}=$ umur pembangkit

$\mathrm{P}=$ modal awal untuk membangun stasiun atau total investasi

$\mathrm{S}=$ biaya penyelamatan (salvage) pada akhir umur pembang-kit atau nilai sisa proyek atau dapat pula dikatakan sebagai scrap value (nilai memo). Untuk penelitian ini scrap value dianggap habis.

$\mathrm{r}=$ laju tahunan dari bunga

$\mathrm{q}=$ total depresiasi

\section{E. Net Present Value (NPV)}

Net Present Value adalah nilai sekarang dari arus kas pada masa yang akan datang yang didiskontokan dengan biaya modal rata-rata yang digunakan (weighted average cost of capital) kemudian dikurangi dengan nilai investasi yang telah dikeluarkan [10]. Net Present Value dapat dirumuskan dengan persamaan sebagai berikut [5]:

$$
\mathrm{NPV}=\left(\mathrm{A} \times \frac{1}{(1+\mathrm{k})^{\mathrm{n}}}\right)-\mathrm{I}
$$

Di mana :

\section{$\mathrm{NPV}=$ Net Present Value}

$\mathrm{A}=$ Arus Kas Netto (Rupiah)

$\mathrm{K}$ = Tingkat suku bunga

$\mathrm{N}=$ Jumlah tahun

I = Investasi Awal (Rupiah)

Di sini kita bisa memisahkan faktor tingkat suku bunga, yaitu bagian yang ada di dalam tanda kurung, yang biasa disebut sebagai discount factor. Jadi discount factor untuk $\mathrm{n}$ tahun, dengan tingkat suku bunga $\mathrm{k}$ akan sma dengan [5] :

$$
\frac{1}{(1+k)^{n}}
$$

Sehingga persamaan (2-1) dapat disederhanakan menjadi:

$$
N P V=\left(A \times F_{d}\right)-I
$$

Di mana :

\section{$\mathrm{Fd}=$ Discount factor}

\section{F. Internal Rate of Return (IRR)}

Internal rate of return adalah discount rate yang menyamakan nilai sekarang (present value) dari arus kas masuk dan nilai invetasi suatu usaha, dengan kata lain IRR adalah discount rate yang menghasilkan $\mathrm{NPV}=0$. Jika biaya modal suatu usaha lebih besar dari IRR, maka NPV menjadi negatif sehingga usaha tesb tidak layak untuk diambil.Jadi semakin tinggi IRR dibandingkan dengan biaya modalnya, semakin baik usaha tersebut untuk dipilih. Sebaliknya, jika IRR lebih kecil daripada biaya modalnya, proyek tersebut tidak akan diambil. Jadi biaya modal maksimum yang dapat ditanggung suatu usaha adalah sebesar [11]. Internal Rate of Return dapat dirumuskan dengan persamaan sebagai berikut :

$$
\mathrm{IRR}=\mathrm{r} 1+(\mathrm{r} 2-\mathrm{r} 1) \times \frac{\mathrm{NPV} 1}{\mathrm{NPV} 1-|\mathrm{NPV} 2|}
$$

Di mana :

$\mathrm{i}_{1}=$ tingkat bunga 1 (tingkat discount rate yang menghasilkan NPV1)

$\mathrm{i}_{2}=$ tingkat bunga 2 (tingkat discount rate yang menghasilkan NPV2)

NPV1 = net present value 1

NPV 2 = net present value 2

Kriteria yang dipilih untuk menentukan kelayakan dengan $: I R R \geq r 1$, berarti proyek layak atau dapat dilanjutkan sedangkan IRR $\leq \mathrm{r} 1$, berarti proyek tidak layak atau tidak dapat dilanjutkan. 


\section{METODE PENELITIAN}

Studi ini dilaksanakan di PLTS Kodingareng pada bulan April-Juli 2018. Penelitian ini diawali dengan dari tahap studi literatur, pengumpulan data primer maupun sekunder (data pembangkit PLTS Kodingareng berupa data spesifikasi mesin, data operasional, data kerusakan komponen, data biaya $O \& M$ (Operation \& Maintenance), data biaya penggantian atau rekondisi komponen rusak) serta tahap akhir yaitu penyelesaian data atau analisis data dengan metode Net Present Value (NPV) dan metode Internal Rate of Return (IRR).

Analisis data pada studi ini dibagi menjadi dua skema rekondisi. Rekondisi skema 1 diasumsikan perbaikan ataupun penggantian komponen yang mengalami kerusakan tanpa merubah jumlah dan spesifikasi dari komponen yang rusak tersebut. Sehingga jika telah dilakukan rekondisi skema 1, maka tidak ada perubahan dari spesifikasi komponen maupun jumlah komponen dari PLTS Kodingareng. Kemudian akan dihitung kelayakan investasi terhadap rekondisi skema 1 dengan menggunakan metode NPV dan metode IRR.

AdapunRekondisi skema 2diasumsikanredesain PLTS sehingga dilakukan analisis perencanaan pembangkit PLTS terkhusus pada komponen baterai yang akan disesuaikan dengan kebutuhan yaitu berdasarkan jumlah panel surya yang telah terpasang dan kapasitas pembangkit terpasang, karena akan sangat disayangkan jika kapasitas yang akan diganti nantinya terlalu besar dari kapasitas yang seharusnya menampung kemampuan daya serap dari panel surya yang telah ada.

\section{HASIL DAN PEMBAHASAN}

Berdasarkan metode penelitian data-data yang dibutuhkan untuk menganalisis kelayakan dari aspek finansial yaitu data spesifikasi mesin, data operasional mesin pada saat masih beroperasi, data kerusakan komponen, data biaya O\&M (Operation and Maintenance) dan data biaya rekondisi mesin yang rusak. Kemudian akan dibagi dua sub bab pembahasan masing-masing untuk setiap rekondisi skema.

\section{A. Rekondisi Skema 1}

Analisis yang dilakukan terbagi menjadi 2 yaitu analisis untuk rekondisi skema 1 dan analisis untuk rekondisi skema 2. Hal yang membedakan dari analisis kedua skema ini yaitu pada skema 2 penulis menghitung dan merencanakan terlebih dahulu kebutuhan baterai yang sesuai dengan kapasitas pembangkit berdasarkan jumlah modul yang telah tersedia.

Analisis rekondisi skema 1 yaitu dimana semua komponen yang mengalami kerusakan diganti sesuai dengan spesifikasi awal PLTS Kodingareng dinyatakan tidak layak, terbukti dengan hasil perhitungan menggunakan 2 metode yaitu metode Net Present Value (NPV) dan metode Internal Rate of Return (IRR).

Dengan memperhitungkan kenaikan harga jual/kWh serta kenaikan biaya O\&M dan biaya upah operator berdasarkan salah satu faktor kenaikan harga beli suatu barang yaitu inflasi yang ada di Indonesia, Arus kas netto yang diperoleh tidak dapat menutupi biaya investasi yang telah dikeluarkan atas pergantian beberapa komponen yang rusak.
TABEL 2

TABEL HASIL ANALISIS METODE NPV PADA REKONDISI SKEMA 1

\begin{tabular}{|c|c|c|c|c|c|c|c|c|}
\hline \multirow[b]{2}{*}{ No } & \multirow[b]{2}{*}{ Tahun } & \multirow[b]{2}{*}{$\begin{array}{c}\text { Daya } \\
\text { Bangkit } \\
\text { [Watt] }\end{array}$} & \multirow[b]{2}{*}{$\begin{array}{c}\text { Harga } \\
\text { Jual/kWh } \\
\text { [Rupiah] }\end{array}$} & \multicolumn{5}{|c|}{ Skema 1} \\
\hline & & & & \begin{tabular}{|c|} 
Total Annual \\
Cost/kWh \\
[Rupiah]
\end{tabular} & $\begin{array}{l}\text { Investasi } \\
\text { [Rupiah] }\end{array}$ & $\begin{array}{c}\text { Arus Kas Netto } \\
\text { [Rupiah] }\end{array}$ & $\begin{array}{c}\text { NPV } \\
\text { [Rupiah] }\end{array}$ & Keterangan \\
\hline 1 & 2018 & 21,818 & 1,467 & $\begin{array}{l}6783 \\
\end{array}$ & $3,863,510,000$ & $-1,391,832,146$ & \multirow{15}{*}{$-9,781,952,693$} & \multirow{15}{*}{$\begin{array}{c}\text { NPV }<0 \\
\text { TIDAK LAYAK }\end{array}$} \\
\hline 2 & 2019 & 21,818 & 1,584 & 6889 & $3,863,510,000$ & $-1,388,735,353$ & & \\
\hline 3 & 2020 & 21,818 & 1,711 & 7176 & $3,863,510,000$ & $-1,430,900,505$ & & \\
\hline 4 & 2021 & 21,818 & 1,848 & 7479 & $3,863,510,000$ & $-1,474,268,789$ & & \\
\hline 5 & 2022 & 21,818 & 1,996 & 7797 & $3,863,510,000$ & $-1,518,825,347$ & & \\
\hline 6 & 2023 & 21,818 & 2,156 & 8131 & $3,863,510,000$ & $-1,564,548,444$ & & \\
\hline 7 & 2024 & 21,818 & 2,328 & 8483 & $3,863,510,000$ & $-1,611,408,627$ & & \\
\hline 8 & 2025 & 21,818 & 2,514 & 8852 & $3,863,510,000$ & $-1,659,367,799$ & & \\
\hline 9 & 2026 & 21,818 & 2,715 & 9240 & $3,863,510,000$ & $-1,708,378,209$ & & \\
\hline 10 & 2027 & 21,818 & 2,933 & 9649 & $3,863,510,000$ & $-1,758,381,337$ & & \\
\hline 11 & 2028 & 21,818 & 3,167 & 10078 & $3,863,510,000$ & $-1,809,306,682$ & & \\
\hline 12 & 2029 & 21,818 & 3,421 & 10529 & $3,863,510,000$ & $-1,861,070,427$ & & \\
\hline 13 & 2030 & 21,818 & 3,694 & 11003 & $3,863,510,000$ & $-1,913,573,978$ & & \\
\hline 14 & 2031 & 21,818 & 3,990 & 11501 & $3,863,510,000$ & $-1,966,702,375$ & & \\
\hline 15 & 2032 & 21,818 & 4,309 & 12025 & $3,863,510,000$ & $-2,020,322,542$ & & \\
\hline
\end{tabular}

TABEL 3

TABEL HASIL ANALISIS METODE IRR PADA REKONDISI SKEMA 1

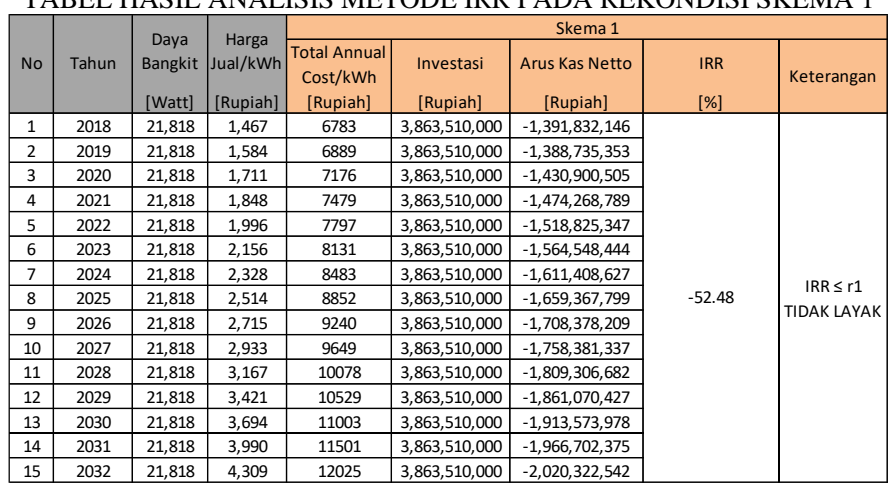

Pada metode NPV diperoleh nilai NPV sebesar Rp.9.781.952.693,- dimana kriteria kelayakan untuk metode NPV adalah jika NPV < 0 maka proyek akan dinyatakan tidak layak atau tidak dapat dilanjut. Demikian pula dengan hasil perhitungan dengan metode IRR diperoleh nilai IRR $-52,48 \%$, dimana kriteria kelayakan untuk metode IRR adalah jika IRR $\leq$ r1 maka proyek akan dinyatakan tidak layak. Sehingga untuk perolehan nilai IRR yaitu $-52,48 \% \leq 4,5 \%$ dinyatakan tidak layak.

\section{B. Rekondisi Skema 2}

Pada rekondisi skema 2 penulis menghitung ulang kapasitas baterai yang sesuai berdasarkan jumlah panel surya atau modul PV yang telah tersedia. Hasil perhitungan perancangan kapasitas baterai menunjukkan bahwa baterai yang akan digunakan pada PLTS Kodingareng adalah baterai dengan spesifikasi $200 \mathrm{Ah}, 2 \mathrm{~V}$ per baterainya.

Sehingga pada rekondisi skema 2 spesifikasi baterai telah diubah berdasarkan hasil perhitungan kapasitas baterai. Salah satu acuan spesifikasi baterai diubah menjadi lebih kecil dikarenakan telah tersedia panel surya dengan jumlah 2106 modul, jika kapasitas beterai dari spesifikasi awal tetap dipertahankan makan akan terjadi pemborosan karena kapasitas baterai yang terlalu besar yaitu $2250 \mathrm{Ah}$ per baterainya.

Jika spesifikasi baterai berubah, maka biaya investasi dalam hal ini biaya penggantian untuk baterai akan diganti sesuai dengan spesifikasi yang telah dihitung sebelumnya akan turut berubah. Sehingga ada perubahan jumlah investasi keseluruhan pada rekondisi skema 2 menjadi Rp. 338.510 .000 ,- 
di mana jumlah nya jauh lebih murah dibanding jumlah investasi keseluruhan pada rekondisi skema 1 yaitu Rp. 3.863.510.000,-

Lebih murahnya jumlah investasi keseluruhan pada rekondisi skema 2 karena komponen biaya penggantian yang paling mahal adalah biaya penggantian komponen baterai. Sehingga pada perhitungan kelayakan rekondisi skema 2 arus kas netto dapat menutupi biaya investasi yang dikeluarkan, terbukti dengan perhitungan arus kas netto yang bernilai positif.

TABEL 4

TABEL HASIL ANALISIS METODE NPV PADA REKONDISI SKEMA 2

\begin{tabular}{|c|c|c|c|c|c|c|c|c|}
\hline \multirow[b]{2}{*}{ No } & \multirow[b]{2}{*}{ Tahun } & \multirow[b]{2}{*}{$\begin{array}{c}\text { Daya } \\
\text { Bangkit } \\
\text { [Watt] }\end{array}$} & \multirow[b]{2}{*}{$\begin{array}{c}\text { Harga } \\
\text { Jual/kWh } \\
\text { [Rupiah] }\end{array}$} & \multicolumn{5}{|c|}{ Skema 2} \\
\hline & & & & $\begin{array}{c}\text { Total Annual } \\
\text { Cost/kWh } \\
\text { [Rupiah] }\end{array}$ & $\begin{array}{l}\text { Investasi } \\
\text { [Rupiah] }\end{array}$ & $\begin{array}{c}\text { Arus Kas Netto } \\
\text { [Rupiah] }\end{array}$ & $\begin{array}{c}\text { NPV } \\
\text { [Rupiah] }\end{array}$ & keterangar \\
\hline 1 & 2018 & 21,818 & $1,467 \mid$ & 368 & $347,510,000$ & $237,271,646$ & \multirow{15}{*}{$1,097,887,887$} & \multirow{15}{*}{$\begin{array}{l}\text { NPV }>0 \\
\text { LAYAK }\end{array}$} \\
\hline 2 & 2019 & 21,818 & 1,584 & 382 & $347,510,000$ & $262,212,772$ & & \\
\hline 3 & 2020 & 21,818 & 1,711 & 396 & $347,510,000$ & $289,315,813$ & & \\
\hline 4 & 2021 & 21,818 & 1,848 & 411 & $347,510,000$ & $318,762,254$ & & \\
\hline 5 & 2022 & 21,818 & 1,996 & 427 & $347,510,000$ & $350,748,535$ & & \\
\hline 6 & 2023 & 21,818 & 2,156 & 444 & $347,510,000$ & $385,487,269$ & & \\
\hline 7 & 2024 & 21,818 & 2,328 & 462 & $347,510,000$ & $423,208,565$ & & \\
\hline 8 & 2025 & 21,818 & 2,514 & 480 & $347,510,000$ & $464,161,442$ & & \\
\hline 9 & 2026 & 21,818 & 2,715 & 500 & $347,510,000$ & $508,615,379$ & & \\
\hline 10 & 2027 & 21,818 & 2,933 & 520 & $347,510,000$ & $556,861,972$ & & \\
\hline 11 & 2028 & 21,818 & 3,167 & 542 & $347,510,000$ & $609,216,733$ & & \\
\hline 12 & 2029 & 21,818 & 3,421 & 565 & $347,510,000$ & $666,021,036$ & & \\
\hline 13 & 2030 & 21,818 & 3,694 & 588 & $347,510,000$ & $727,644,217$ & & \\
\hline 14 & 2031 & 21,818 & 3,990 & 613 & $347,510,000$ & $794,485,842$ & & \\
\hline 15 & 2032 & 21,818 & 4,309 & 640 & $347,510,000$ & $866,978,161$ & & \\
\hline
\end{tabular}

TABEL 5

TABEL HASIL ANALISIS METODE IRR PADA REKONDISI SKEMA 2

\begin{tabular}{|c|c|c|c|c|c|c|c|c|}
\hline \multirow[b]{2}{*}{ No } & \multirow[b]{2}{*}{ Tahun } & \multirow[b]{2}{*}{$\begin{array}{c}\text { Daya } \\
\text { Bangkit } \\
\text { [Watt] }\end{array}$} & \multirow[b]{2}{*}{$\begin{array}{c}\text { Harga } \\
\text { Jual/kWh } \\
\text { [Rupiah] }\end{array}$} & \multicolumn{5}{|c|}{ Skema 2} \\
\hline & & & & $\begin{array}{c}\text { Total Annual } \\
\text { Cost/kWh } \\
\text { [Rupiah] }\end{array}$ & $\begin{array}{l}\text { Investasi } \\
\text { [Rupiah] }\end{array}$ & $\begin{array}{c}\text { Arus Kas Netto } \\
\text { [Rupiah] }\end{array}$ & $\begin{array}{l}\text { IRR } \\
{[\%]}\end{array}$ & keteranga \\
\hline 1 & 2018 & 21,818 & \begin{tabular}{|l|}
1,467 \\
\end{tabular} & 368 & $347,510,000$ & $237,271,646$ & \multirow{15}{*}{24.23} & \multirow{15}{*}{$\begin{array}{l}\text { IRR } \geq r 1 \\
\text { LAYAK }\end{array}$} \\
\hline 2 & 2019 & 21,818 & 1,584 & 382 & $347,510,000$ & $262,212,772$ & & \\
\hline 3 & 2020 & 21,818 & 1,711 & 396 & $347,510,000$ & $289,315,813$ & & \\
\hline 4 & 2021 & 21,818 & 1,848 & 411 & $347,510,000$ & $318,762,254$ & & \\
\hline 5 & 2022 & 21,818 & 1,996 & 427 & $347,510,000$ & $350,748,535$ & & \\
\hline 6 & 2023 & 21,818 & 2,156 & 444 & $347,510,000$ & $385,487,269$ & & \\
\hline 7 & 2024 & 21,818 & 2,328 & 462 & $347,510,000$ & $423,208,565$ & & \\
\hline 8 & 2025 & 21,818 & 2,514 & 480 & $347,510,000$ & $464,161,442$ & & \\
\hline 9 & 2026 & 21,818 & 2,715 & 500 & $347,510,000$ & $508,615,379$ & & \\
\hline 10 & 2027 & 21,818 & 2,933 & 520 & $347,510,000$ & $556,861,972$ & & \\
\hline 11 & 2028 & 21,818 & 3,167 & 542 & $347,510,000$ & $609,216,733$ & & \\
\hline 12 & 2029 & 21,818 & 3,421 & 565 & $347,510,000$ & $666,021,036$ & & \\
\hline 13 & 2030 & 21,818 & 3,694 & 588 & $347,510,000$ & $727,644,217$ & & \\
\hline 14 & 2031 & 21,818 & 3,990 & 613 & $347,510,000$ & $794,485,842$ & & \\
\hline 15 & 2032 & 21,818 & 4,309 & 640 & $347,510,000$ & $866,978,161$ & & \\
\hline
\end{tabular}

Dari hasil analisis tersebut dinyatakan layak, terbukti dengan hasil perhitungan menggunakan 2 metode yaitu metode Net Present Value (NPV) dan metode Internal Rate of Return (IRR). Pada metode NPV diperoleh nilai NPV sebesar Rp. 1.112.194.399,-- di mana kriteria kelayakan untuk metode NPV adalah jika NPV > 0 maka proyek akan dinyatakan layak atau dapat dilanjut. Demikian pula dengan hasil perhitungan dengan metode IRR diperoleh nilai IRR $24,24 \%$, di mana kriteria kelayakan untuk metode IRR adalah jika IRR $\geq$ r1 maka proyek akan dinyatakan layak. Sehingga untuk perolehan nilai IRR yaitu $24,24 \% \geq 4,5 \%$. Selengkapnya dapat dilihat pada tabel perbandingan hasil analisis rekondisi skema 1 dan skema 2 pada Tabel 6 dan Tabel 7.
TABEL 6

TABEL HASIL PERBANDINGAN ANALISIS METODE NPV PADA REKONDISI SKEMA 1 DAN 2

\begin{tabular}{|c|c|c|c|}
\hline \multicolumn{2}{|c|}{ Skema 1 } & \multicolumn{2}{c|}{ Skema 2 } \\
\hline $\begin{array}{c}\text { NPV } \\
\text { Rupiah] }\end{array}$ & Keterangan & $\begin{array}{c}\text { NPV } \\
{[\text { Rupiah }]}\end{array}$ & Keterangan \\
\hline$-9,781,952,693$ & NPV < 0 TIDAK LAYAK & $1,097,887,887$ & NPV > 0 LAYAK \\
\hline
\end{tabular}

TABEL 7

TABEL HASIL PERBANDINGAN ANALISIS METODE IRR PADA REKONDISI SKEMA 1 DAN 2

\begin{tabular}{|c|c|c|c|}
\hline \multicolumn{2}{|c|}{ Skema 1 } & \multicolumn{2}{c|}{ Skema 2 } \\
\hline IRR & Keterangan & IRR & Keterangan \\
{$[\%]$} & & {$[\%]$} & \\
\hline-52.48 & IRR $\leq$ r1 TIDAK LAYAK & 24.23 & IRR $\geq$ r1 LAYAK \\
\hline
\end{tabular}

\section{KESIMPULAN}

Berdasarkan tujuan penelitian ini, maka dapat disimpulkan beberapa hal dari hasil analisis kelayakan finansial untuk rekondisi PLTS Kodingareng sebagai berikut :

1). Dari hasil analisis kelayakan finansial rekondisi skema 1 dengan menggunakan metode Net Present Value (NPV) dan metode Internal Rate of Return (IRR) diperoleh hasil tidak layak pada kedua metode karena arus kas yang diperoleh tidak lebih besar atau tidak dapat menutupi biaya investasi yang dikeluarkan. Adapun dari hasil analisis kelayakan finansial rekondisi skema 2 dengan metode Net Present Value (NPV) dan metode Internal Rate of Return (IRR) diperoleh hasil layak pada kedua metode karena keuntungan yang diperoleh dapat menutupi biaya investasi yang dikeluarkan.

2). Pada rekondisi skema 1 perbaikan dan penggantian komponen-komponen yang mengalami kerusakan dapat diganti sesuai dengan spesifikasi awal pembangkit, namun tidak akan menguntungkan atau dapat dikatakan tidak layak diperbaiki ataupun diganti dari segi finansial. Sedangkan pada rekondisi skema 2 penulis melakukan perhitungan ulang menyangkut kapasitas komponen yang akan diganti sehingga perbaikan dan penggantian komponen sesuai dengan kebutuhan pembangkit menghasilkan keuntungan atau dapat dikatakan layak dari segi finansial.

3). Kedepannya dapat dilakukan penelitian lebih lanjut mengenai analisis kelayakan jika PLTS Kodingareng dapat di hybrid dengan PLTD untuk menghasilkan efisiensi lebih baik dan penghematan pada sisi pengoperasian PLTD.

\section{REFERENSI}

[1] Discover The Newest World Power, Frederick Court, Maryland, USA.

[2] R. Salman, "Analisa perencanaan penggunaan sistem pembangkit listrik tenaga surya (PLTS) untuk Perumahan (Solar Home System)", Majalah Bina Teknik Fakultas Teknik Universitas Negeri Medan, Vol.11 No.1, hal. 46-51, Medan, 2013

[3] M. Bachtiar, "Prosedur perancangan sistem pembangkit listrik tenaga surya untuk perumahan (solar home system)", Jurnal SMARTek, 4(3), hal 176-182, Palu, 2006.

[4] Suratman. Studi Kelayakan Proyek: Teknik dan Prosedur Penyusunan Laporan, Jakarta: Ghalia Indonesia, 2001 
[5] S. Husnan dan S. Muhammad, Studi Kelayakan Proyek, UPP AMP YKPN. Yogyakarta, 2000.

[6] A.A. Octaviani, "Analisa ekonomi pembangunan pembangkit listrik tenaga mikrohidro di Desa Megamendung Kecamatan Megamendung, Kabupaten Bogor, Jawa Barat," Skripsi, Institut Pertanian Bogor, Bogor, 2012.

[7] J. P. Gittinger, Analisa Ekonomi Proyek-Proyek Pertanian. Edisi Kedua, UI Press-John Hopkins, Jakarta, 1986.

[8] R. J. Kodoatie, Analisis Ekonomi Teknik, Andi Offset, Yogyakarta, 1997.

[9] "Perhitungan biaya operasional pembangkit listrik," Bahan ajar, Tidak diterbitkan, Jurusan Teknik Pembangkit Energi, Politeknik Negeri Ujung Pandang, Makassar.

[10] A. Afifuddin, "Analisis dampak krisis global terhadap kelayakan PLTA Pamona 2," Skripsi, Tidak diterbitkan, Fakultas Ekonomi Universitas Indonesia, Jakarta, 2009.

[11] I. Diatin, M. P., dan I. Irianni, "Finansial analysis of Wanayasa Tilapia Culture in Mekarsari Farmer Group", Jurnal Akuakultur Indonesia, 6(1), hal. 97-102, 2007. 